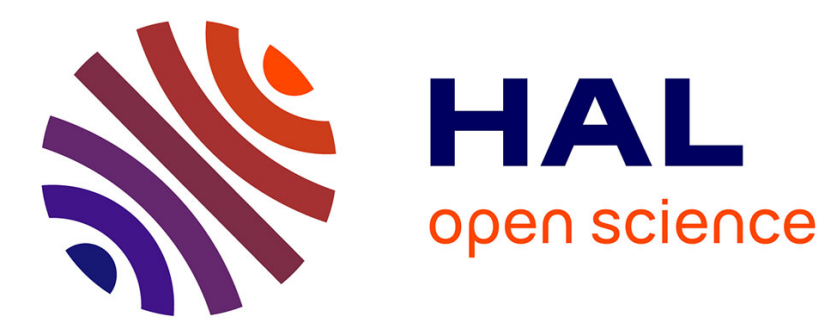

\title{
Materials for solar photocells :Place of CdTe
}

M. Rodot

\section{- To cite this version:}

M. Rodot. Materials for solar photocells :Place of CdTe. Revue de Physique Appliquée, 1977, 12 (2), pp.411-416. 10.1051/rphysap:01977001202041100 . jpa-00244183

\section{HAL Id: jpa-00244183 https://hal.science/jpa-00244183}

Submitted on 1 Jan 1977

HAL is a multi-disciplinary open access archive for the deposit and dissemination of scientific research documents, whether they are published or not. The documents may come from teaching and research institutions in France or abroad, or from public or private research centers.
L'archive ouverte pluridisciplinaire HAL, est destinée au dépôt et à la diffusion de documents scientifiques de niveau recherche, publiés ou non, émanant des établissements d'enseignement et de recherche français ou étrangers, des laboratoires publics ou privés. 
II. 2. b) CdTe solar cells.

\title{
MATERIALS FOR SOLAR PHOTOCELLS : PLACE OF CdTe
}

\author{
M. RODOT
}

Laboratoire de Physique des Solides C. N. R. S., 1, place Aristide-Briand, 92190 Meudon, France

Résumé. - Le choix des meilleurs matériaux pour la conversion photovoltaïque est guidé par les considérations suivantes :

- largeur de la bande interdite et nature des transitions bande-à-bande,

- valeur de la durée de vie des photoporteurs en fonction du dopage,

- aptitude du matériau à être préparé économiquement en grandes surfaces, avec de bonnes propriétés électroniques,

- possibilité de former des structures collectrices efficaces,

- aptitude de la cellule à travailler sous rayonnement concentré.

Ces critères de qualité seront établis en général, puis appliqués à $\mathrm{CdTe}$. On montre que CdTe est l'un des matériaux les plus prometteurs. Une revue des travaux passés confirme partiellement cette conclusion, mais des preuves précises de la valeur des cellules au CdTe doivent encore être obtenues.

\footnotetext{
Abstract. - The choice of the best materials for photovoltaïc conversion is guided by several considerations :

- the value of the energy bandgap and the nature of the band-to-band transitions,

- the value of photocarrier lifetime as a function of doping,

- the ability of the material to be prepared economically in large areas, with good electronic properties,

- the ability to form efficient collecting structures.

- the ability of the cell to work eventually under concentrated radiation.

These quality criteria will be established on a general basis, and then applied to CdTe. It is shown that CdTe is one of the most promising materials. Review of past work partly confirms this conclusion, but definite proofs of the value of CdTe cells are still to be obtained.
}

Figure 1 was drawn by the present author in 1967 [1] as a guess of future performances of CdTe solar cells. None of the predictions indicated by dotted lines was really verified, since most of the research on CdTe solar
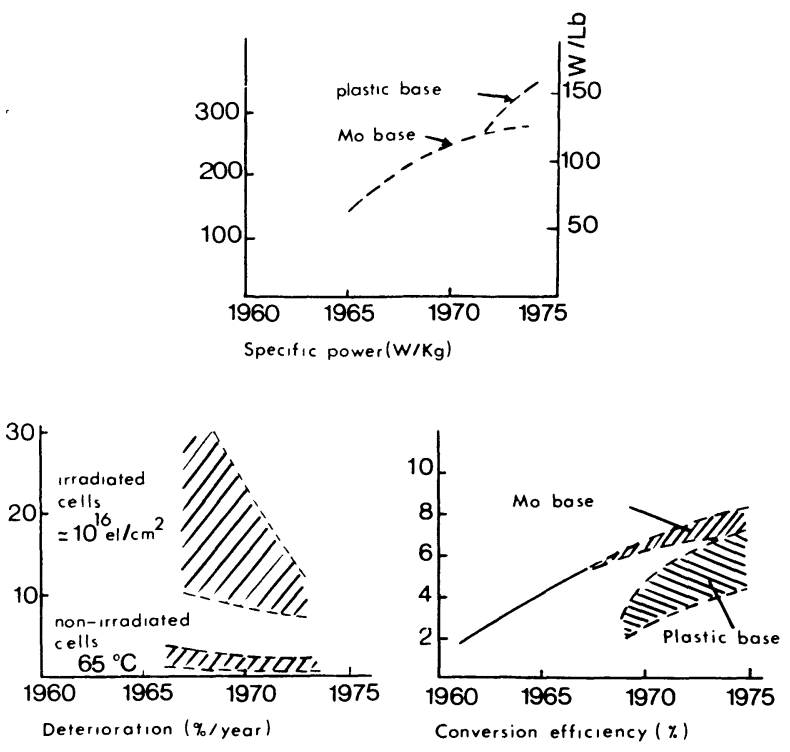

Fig. 1. - Predicted progress in the performance of CdTe photoelectric cells (bare cell, without filter or accessories) [1]. cells was stopped in the years 1968-1973. With the new challenge of the terrestrial applications of solar cell, it is interesting to review in this perspective the possibilities of $\mathrm{CdTe}$, since high efficiencies were already available in 1963 [2].

1. Goals of research on new solar cells. - For this purpose, we have first to define realistic goals for terrestrial solar cells. Let us consider two objectives of unequal difficulty :

a) powering water pumps in Sahel. Competitivity will be ensured if water pumped from $20 \mathrm{~m}$ costs no more than $0.15 \mathrm{~F} / \mathrm{m}^{3}$ :

b) building a power station in an isolated site. Competitivity requires a maximum cost of $0.50 \mathrm{~F} / \mathrm{kWh}$.

Present solar cells, using Si single crystals and used without concentration, lead to a cost of $1.5 \mathrm{~F} / \mathrm{m}^{3}$ for the first application (10 times too much) or $15 \mathrm{~F} / \mathrm{kWh}$ for the second one (30 times too much).

The first, less ambitious objective can be fulfilled by classical Si cells since it is expected that by 1980 the cost of the latter will be decreased by a factor of 3 (without major technical changes) and the use of concentration 
will bring another favourable factor of 3 or 4 . But the second, more ambitious objective seems to be out of reach of the present technology. The reason for this lies essentially in the cost of the material, which is now $4000 \mathrm{~F} / \mathrm{m}^{2}$, i. e. $40 \%$ of the cell cost, but may not easily go below $2500 \mathrm{~F} / \mathrm{m}^{2}$, i. e. $80 \%$ of the 1980 cell cost. We conclude that other materials are required for future expansion of photovoltaic conversion.

These new materials, which may be $\mathrm{Si}$ ribbon or polycrystalline $\mathrm{Si}$ as well as $\mathrm{Cu}_{2} \mathrm{~S}$ or $\mathrm{CdTe}$ or $\mathrm{GaAs}$, should cost less than $500 \mathrm{~F} / \mathrm{m}^{2}$ to meet objective $b$ ) above. This is a first requirement for a new generation of solar cells.

A second requirement concerns efficiency. For a given cell cost, a minimum efficiency $\eta_{\min }$ is required to meet a given goal. Figure 2 [3] shows $\eta_{\min }$ as a result of

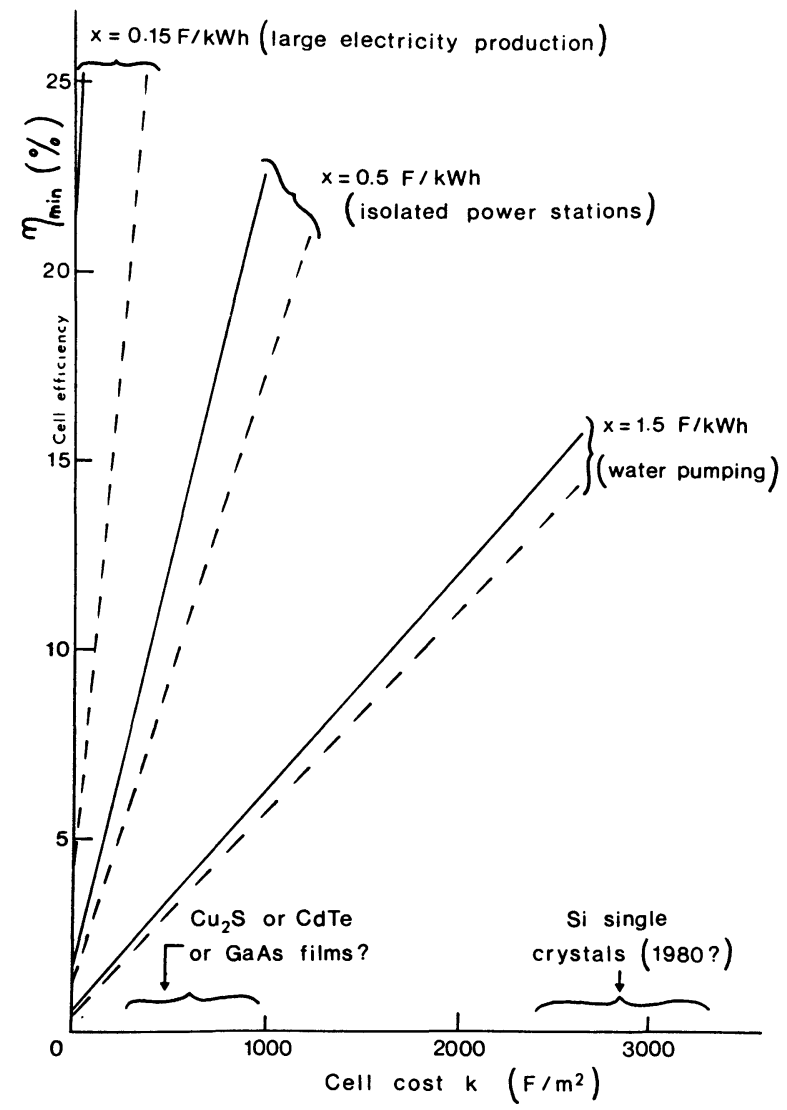

Fig. 2. - Minimum cell efficiency $\left(\eta_{\mathrm{min}}\right)$ required, for a given cell cost (k), to reach a given cost of electricity (x) without use of concentration [3] : - . . . . - without storage, with storage $(6 \mathrm{hrs})$.

a calculation taking in account the expected costs of cell supports, electro-technics associated with the cells (including a moderate storage) and other elements of the total cost of the generator. It can be seen that, even with cell cost as low as $500 \mathrm{~F} / \mathrm{m}^{2}$, efficiency should overpass $10 \%$ to meet objective $b$ ). Note that an eventual objective $c$ ), which would be massive production of electricity, is almost entirely out of the scope of figure 2, which leaves this possibility open only in the long range (next century ?).

Figure 2 was drawn without using concentration of solar radiation. The negative and positive consequences of concentration on cost can be evaluated, leading to an overall positive effect shown by figure 3 [3]. This effect

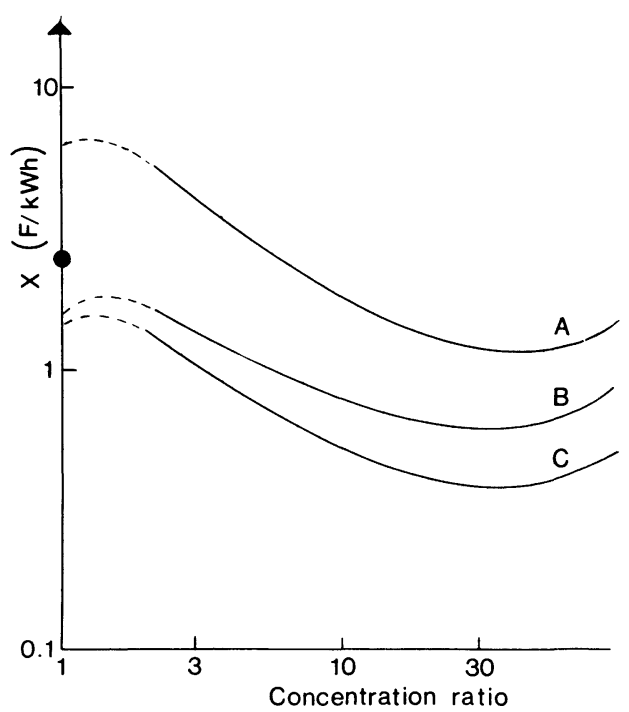

Fig. 3. - Cost of electricity produced by $\mathrm{Si}$ cells under concentration [3]. $\Delta$ Present $\cdot$ cells $\left(11000 \mathrm{~F} / \mathrm{m}^{2}\right)$ without concentration. Curve A : present cells with concentrator cost $1000 \mathrm{~F} / \mathrm{m}^{2} .1980$ (?) cells $\left(2400 \mathrm{~F} / \mathrm{m}^{2}\right)$ without concentration. Curve B : 1980 cells with concentrator cost $600 \mathrm{~F} / \mathrm{m}^{2}$. Curve C : 1980 cells with concentrator cost $300 \mathrm{~F} / \mathrm{m}^{2}$.

is important (curve A) for present solar cells, less important but still meaningful for future (1980) Si single crystal solar cells. Though exact calculations for other cells would require a knowledge of the variation of efficiency vs. concentration, it is expected that the cost gain associated with concentration may be smaller for low cost thin film cells than for Si single crystal cells, and probably marginal in the concentration range of figure 3.

We conclude that new, improved types of solar cells should possess the following qualities : cell cost of the order of $500 \mathrm{~F} / \mathrm{m}^{2}$ or less ; efficiency higher than $10 \%$; if possible, ability to work under high concentrations.

2. Necessary qualities of a material for solar cells. a) The first important requirement is that thin films of good electronic quality should be feasible in large areas. This implies a selection of both materials and elaboration processes. The word good electronic quality refers to the properties of the most perfect single crystals, which should not be degraded by the chosen technique.

b) As is well known [4], the optimization of photon absorption leads to two requirements. First there exists an optimum energy gap $E_{\mathrm{g}}$, in order to minimize losses due to both unabsorbed photons $\left(h v<E_{\mathrm{g}}\right)$ and too 
energetic photons $\left(h v \gg E_{\mathrm{g}}\right)$. For ideal diodes, this optimum energy gap has been computed to be $1.5 \mathrm{eV}$ for cells working at $300 \mathrm{~K}$, or $1.9 \mathrm{eV}$ for cells working at $500 \mathrm{~K}$. Furthermore the nature of the band-to-band transitions has an important bearing on the cell thickness. The latter should be of the order of the absorption length $1 / \alpha(\alpha=$ mean absorption coefficient for $h v>E_{\mathrm{g}}$ ), which is much smaller ( 2 to $5 \mu \mathrm{m}$ for $\mathrm{Cu}_{2} \mathrm{~S}, \mathrm{CdTe}$ or $\mathrm{GaAs}$ ) for direct, no-phonon transitions than for the case of indirect, phonon-assisted transitions (50 to $100 \mu \mathrm{m}$ for $\mathrm{Si}$ ).

c) The collection of photocarriers is hampered by recombination losses, which depend on the diffusion length $L=\sqrt{D \tau}(\tau=$ minority carrier lifetime, $D=\mu / K T$ where $\mu$ is the minority carrier mobility). To avoid huge recombination losses, the diffusion length should be of the order of the absorption length $1 / \alpha$. Heavy doping of the photoelectric material decreases $L$, while it decreases the series resistance losses of the cell, so that there exists an optimum doping of the material.

d) A fourth required quality is the ability to build an efficient collector junction. The collecting structure could be a p-n junction as is usual for $\mathrm{Si}$, but also a heterojunction, a metal-semiconductor barrier or a MIS structure.

e) Furthermore the material itself and the complete cell should be reliable. This is a very stringent requirement, since the data of figures 2 and 3 were computed for an assumed lifetime of the cells of 20 years, which is at the moment a very optimistic value.

$f$ ) Finally the aptitude to concentration is also a property related to both the material and the structure.

The remaining of this paper tries to answer the question : does CdTe meet these six requirements ?

3. Elaboration processes for thin films. - At least five processes may offer the possibility of growing large area thin films of semiconductors.

Crystallization from the melt, which is not usually an industrial process, is largely used for semiconductors. Silicon can be produced either as single crystals, without substrate (edge-defined film growth or Tyco process ; dendritic growth or Westinghouse process) or as polycrystalline layers on a substrate. For CdTe, only this second case is of interest, since the thickness should be only 2 to $5 \mu \mathrm{m}$. No experiment seems to be available about thin CdTe films grown from the melt. Note that this process usually gives good electronic properties and high growth rates, and may be amenable to continuous production; its disadvantages are its high thermodynamic cost (high temperature) and the difficulty to imagine the production of a whole cell by this process.

Little is known about electrolysis as a process to deposit semiconductor thin films. A recent paper on $\mathrm{Si}$ [5] has opened this way, and work on CdTe would be welcomed. Electrolysis is known as a cheap industrial process for preparing large area metallic layers at costs as low as $250 \mathrm{~F} / \mathrm{m}^{2}$.

The spray technique involves the atomization of suitable liquid solutions containing reactant species, and the reaction of the latter giving the wanted thin film in a heated substrate together with other volatile species Industrial use of this technique in the glass industry yields thin films of the order of $250 \mathrm{~F} / \mathrm{m}^{2}$. For semiconductors, its best known application is to CdS$\mathrm{Cu}_{2} \mathrm{~S}$ photocells [6] leading to efficiencies as high as $5 \%$. This technique has a low thermodynamic cost and a good ability to yield large areas, perhaps in continuous production; however the adherence, homogeneity and electronic quality of the film may be difficult to control. The spray technique should probably be applicable to CdTe.

Chemical vapour deposition (C. V. D.) is a wellknown technique for semiconductors, especially $\mathrm{Si}$ and $\mathrm{GaAs}$; other industrial uses are scarce. The thermodynamic cost is moderately low, the growth rate is slow (typically $10 \mu \mathrm{m} / \mathrm{hr}$ ). The process may not be amenable to continuous production of large areas, and to the production of complete cells by only one process. The electronic properties of films deposited on cheap substrates are yet not very good for $\mathrm{Si}$ [6], but are quite satisfactory for CdTe : Cusano's cells, reaching $6 \%$ efficiency, were made by such a technique.

Under the last heading of vacuum techniques we may consider simultaneoulsy sublimation and sputtering. Here the thermodynamic cost is high but the growth rate is high also $(1 \mu \mathrm{m} / \mathrm{min})$. Large areas may be produced, but not continuously. Contrary to the preceding processes, the yield is low, i. e. the ratio of film weight to the weight of the used matter is lower than 1. However glass industry uses these techniques and film costs may be as low as $500 \mathrm{~F} / \mathrm{m}^{2}$. Among semiconductors, Si cannot be produced with good electronic properties by vacuum techniques, but CdTe probably can : at least $\mathrm{CdTe}-\mathrm{HgTe}$ sputtered films have been able to produce high detectivity infrared detectors [7].

It can be concluded that all potentially cheap techniques for film production may be applicable to $\mathrm{CdTe}$, but very little work has been made in this field. It is already sure that polycrystalline thin films of $\mathrm{CdTe}$ may easily have electronic properties similar to those of single crystals, contrary to the case of silicon.

4. Absorption and recombination properties. - The energy gap of CdTe, $E_{\mathrm{g}}=1.44 \mathrm{eV}$, is in principle well suited to solar energy conversion (Fig. 4). Furthermore the energy gap is direct, leading to values of the absorption coefficient much higher than those of Si (Fig. 5).

These favourable properties are not enough to infer that CdTe is a good material for photovoltaic conversion. We must also look at its diffusion length for minority carriers, as mentioned above. 


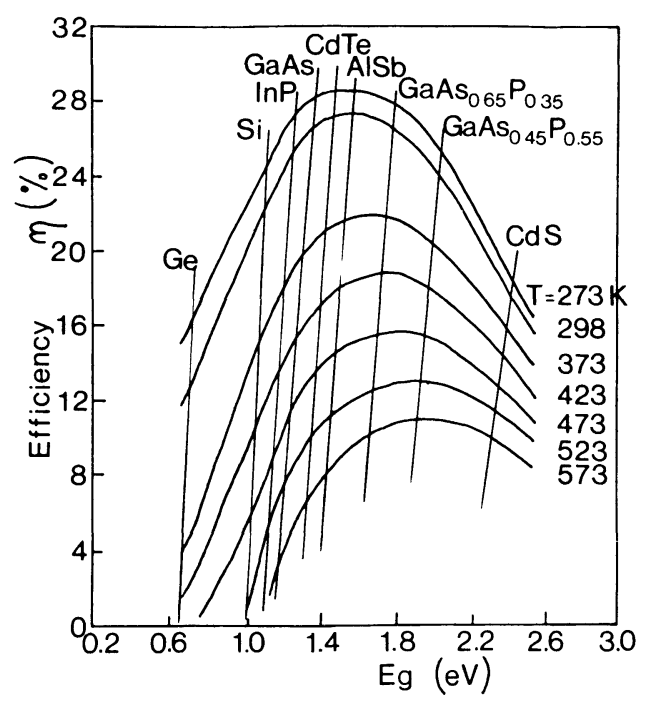

Fig. 4. - Theoretical efficiency of ideal diodes as solar energy converters, vs. energy gap of the photoelectric material [4].

Here we must recognize that information is scarce. By comparison, for silicon we know the capture cross sections of numerous specific impurities (since carrier recombination is mostly through trap levels in the forbidden gap) : see e. g. [9] ; we also know the results of extensive studies of the doping level on the diffusion length : Iles and Soclof [10] give maximum hole lifetimes varying from $12 \mu \mathrm{s}$ for $n=10^{15} \mathrm{~cm}^{-3}$ to $0.02 \mu \mathrm{s}$ for $n=10^{20} \mathrm{~cm}^{-3}$ (the corresponding diffusion lengths vary from 120 to $2 \mu \mathrm{m})$; similar results hold for p-type $\mathrm{Si}$. Some data available for CdTe are compiled in the following table. All these data are not consistent with one another, probably because of the well-known complexity of the point imperfections in $\mathrm{CdTe}$; they do

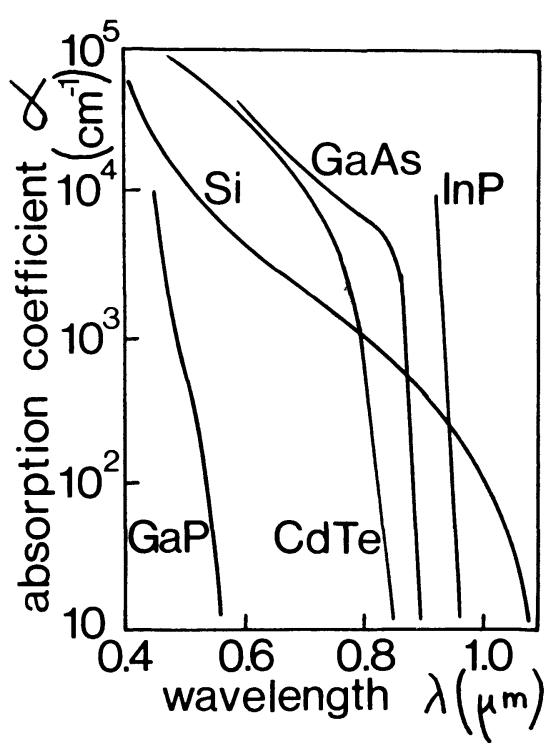

FIG. 5. - Absorption spectrum of some photoelectric materials [8].

not form a complete piece of information. It is seen that diffusion lengths larger than the absorption length may be obtained in compensated $\mathrm{CdTe}$, but the latter is inappropriate to build solar cells because of its too high resistivity. On the other hand, for doped CdTe, the measured diffusion lengths are too small, with perhaps an exception for the data of ref. [14]. Bell et al. [12] have calculated that the theoretical efficiency for a p-n junction with $10^{16} \mathrm{~cm}^{-3}$ doping was $27 \%$ for very large lifetimes, but was reduced to $20 \%$ for $\tau=10^{-7} \mathrm{~s}$, to $10 \%$ for $\tau=10^{-8} \mathrm{~s}$ and to $3 \%$ for $\tau=10^{-9} \mathrm{~s}$. It appears that recombination losses will not be negligible for the doping range $10^{16}-10^{17} \mathrm{~cm}^{-3}$.

Diffusion lengths in CdTe

$$
\begin{gathered}
\text { Purity and dopant } \\
n=5 \times 10^{14} \mathrm{~cm}^{-3}(\text { In }) \\
p=\quad 10^{16} \mathrm{~cm}^{-3}(?) \\
3 \times 10^{16} \text { donors and } \\
\text { acceptors }(\mathrm{Cl} \text {-compensated) } \\
n=6.3 \times 10^{17} \mathrm{~cm}^{-3}(\mathrm{I}) \\
p=1.7 \times 10^{17} \mathrm{~cm}^{-3}(\mathrm{P}) \\
n=5.5 \times 10^{17} \mathrm{~cm}^{-3}(\mathrm{In})
\end{gathered}
$$

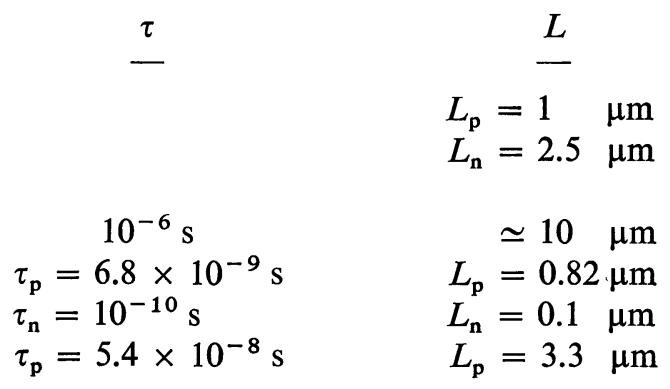

\section{Reference}

To avoid this difficulty, it has been proposed to build an accelerating field inside the solar cell. Experiments by Bouazzi et al. [14] have shown how such a feature, produced by a composition gradient due to alloying, led to an apparent diffusion length $L^{*}$ much higher than the true one : values of $L_{\mathrm{p}}^{*}$ as high as $90 \mu \mathrm{m}$ have been measured. This method is all the more attractive that it minimizes the surface as well as the volume recombination losses.
5. p-n junctions and other structures. - The first CdTe solar cells have been made by depositing a $\mathrm{Cu}_{2} \mathrm{Te}$ film at the surface of CdTe. Similar efficiencies, around 5-6 \%, were obtained in two studies which interpreted the structure differently (probably due to differences in the process used to deposit $\mathrm{Cu}_{2} \mathrm{Te}$ ) : Cusano [2] described the structures as heterojunctions between $\mathrm{p}-\mathrm{Cu}_{2} \mathrm{Te}$ and $\mathrm{n}-\mathrm{CdTe}$; Bernard et al. [15] described them as p-n junctions of $\mathrm{CdTe}$, due to $\mathrm{Cu}$ diffusion 
inside n-CdTe. Figures $6(a)$ and $(b)$ show the corresponding band structure. Cusano [2] has found an optimum doping of the CdTe crystal equal to

(a)

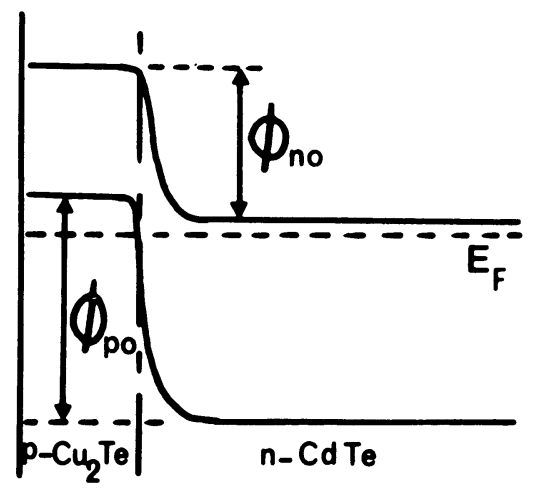

(b)
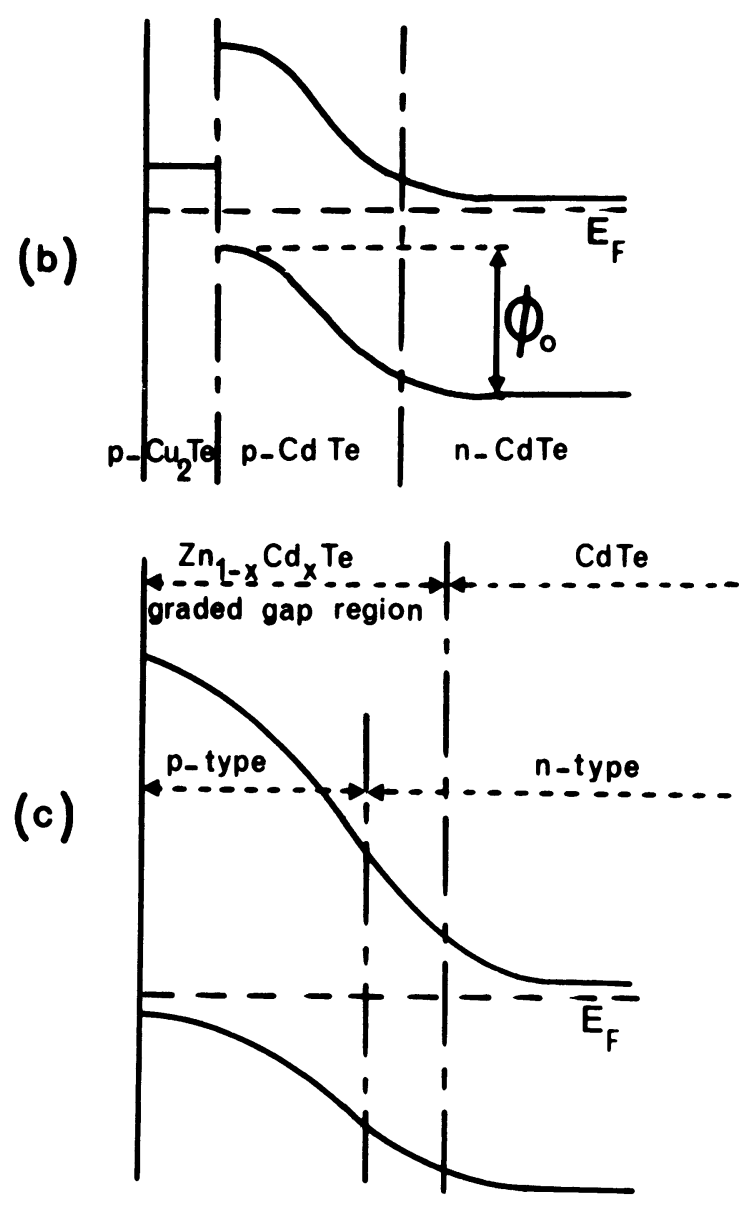

Fig. 6. - Three types of collecting structures: $\mathrm{Cu}_{2} \mathrm{Te}-\mathrm{CdTe}$ hetero junctions. [2], CdTe p-n junctions [15], proposed graded bandgap structures.

$2 \times 10^{15} \mathrm{~cm}^{-3}$ (Fig. 7). Such structures were also prepared on an industrial basis, with the following results [16] : for seventy 3-watt generators using $44 \mathrm{~cm}^{2}$ cells, mean values of open circuit voltage, short-circuit current and efficiency were $0.58 \mathrm{~V}, 14 \mathrm{~mA} / \mathrm{cm}^{2}$ and $5 \%$ respectively.

Other techniques have also been used to prepare $p-n$ junctions. $\mathrm{p}$-n diodes have been prepared by $\mathrm{Al}$ vapour

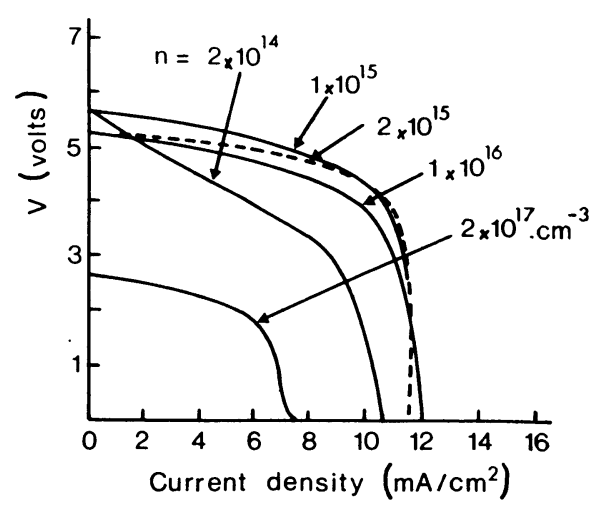

FIG. 7. - Solar cell characteristics as a function of CdTe doping level [2].

diffusion on n-CdTe [13]. In such diodes the forward current was due to thermal processes involving recombination in the space-charge region and the reverse current to tunneling processes, so that these diodes are far from being ideal. Another type of $p-n$ diode has been prepared by close-spaced vapour transport, with reported efficiencies as solar cells of $3.25 \%$ [17].

CdS-CdTe heterojunctions have been studied by two authors [18] [19]. While expected theoretical efficiency reaches $17 \%$, the lattice mismatch between CdS and CdTe is very high $(9.7 \%)$, excluding the preparation of defectless diodes. Practical efficiencies were $4 \%$.

Note added in proof : $8 \%$ has been reached recently (A. L. Fahrenbruch, F. Buch, K. Mitchell, R. Bube, $12 \mathrm{Hr}$ photovoltaic specialist Conference, Baton Rouge, Nov. 1976).

Although numerous papers deal with metal-CdTe or metal-oxide-CdTe structures (see for example several papers of this conference), no such structure seems to have been tested yet as a solar cell.

It appears finally that several possibilities exist to make efficient collecting structures with CdTe. One of the most promising could be the association of a p-n diode with a graded bandgap region (Fig. $6 c$ ). A first approach of such structures, using $\mathrm{ZnHgTe}$ or $\mathrm{CdHgTe}$ alloys, has already led to an efficiency of $4 \%$ [20]. Work has to be continued to characterize the current mechanisms and the photoelectric properties of all these structures, first on good crystals, then on films. On this basis, there is no reason why the presently obtained best cells should not be still largely improved.

6. Reliability. - It is of course too early to discuss the reliability of CdTe solar cells which are still to be made. The only existing data [16] indicated a $10 \%$ maximum degradation in $2000 \mathrm{hr}$ of storage under vacuum at $80^{\circ} \mathrm{C}$, for the Cusano-type solar cells. This is not negligible. In a similar case that has been extensively studied, that of $\mathrm{Cu}_{2} \mathrm{~S}-\mathrm{CdS}$ thin film cells, the degradation has been limited to very low values by suitable encapsulation techniques, choice of $\mathrm{CdS}$ 
doping level and of $\mathrm{Cu}_{2} \mathrm{~S}$ stoichiometry and choice of adequate additions to $\mathrm{CdS}$ to decrease the $\mathrm{Cu}$ diffusion coefficient [21]. The problem is specific to each structure.

7. Ability to concentration. - It is implied by the large value of $E_{\mathrm{g}}$ that ideal CdTe diodes could stand to work at higher than ambient temperatures. A pertinent example is that of GaAs, which was shown [22] both to keep a high efficiency $(17.5 \%)$ at high concentrations (312) and to remain very good $(14 \%)$ at $200{ }^{\circ} \mathrm{C}$. This encouraging result cannot be extrapolated however, and a detailed study of CdTe structures will be in order when these structures will be available.

8. Conclusions. - CdTe has important advantages as a material for solar cells, namely its appropriate value of direct energy gap and its ability to keep good electronic properties under thin film form. This combination of advantage is even unique since GaAs, which shares the first one, has not yet been found to share the second one. On the six main issues deter- mined above, CdTe can be expected to behave favourably.

However the objective which can be reasonably chosen, i. e. to build $10 \%$ efficiency cells at a cost near $500 \mathrm{~F} / \mathrm{m}^{2}$, is far from being reached. Three series of works are necessary to get nearer to these goals :

- on thin film elaboration techniques, several of which are promising for CdTe,

- on the behaviour of diffusion length as a function of the doping level and on the detailed nature of imperfection centers,

- on the elaboration and properties of collecting structures, including p-n junctions, Schottky barriers and graded bandgap structures.

Even if the results of such work are positive, it should be recalled that the long-range future of $\mathrm{CdTe}$ solar cells will also be determined by the success of other types of solar cells, mostly those using $\mathrm{Si}$ ribbons. Si polycrystals and III-V compounds.

\section{References}

[1] RoDot, M., 29th meeting of the propulsion and energetics panel, AGARD. Liège, June 1967.

[2] Cusano, D. A., Solid State Electron. 6 (1963) 217 ; Revue Phys. Appl. 1 (1966) 195.

[3] BARBE, M. (1976) unpublished.

[4] Loferski, J. J., J. Appl. Phys. 27 (1956) 777 ; Proc. IEEE 51. (1963) 667.

[5] Cohen, U., Huggins, R. A., J. Electrochem. Soc. 123 (1976) 381.

[6] Chu, T. L., Mollenkopf, H. C., Singh, K. N., Wu, I. C., 11th Photovoltaïc Specialists Conference, Phoenix, May 1975.

[7] Cohen-Solal, G., Sella, C., Imhoff, D., Zozime, A., Japan J. Appl. Phys., suppl. 2, part 1 (1974) 517.

[8] RAPPAPORT, P., Revue Phys. Appl. 1 (1966) 154.

[9] Bonch-Bruevich, V. L., Landsberg, E. G., Phys. Stat. Sol. 29(1968) 9.

[10] Iles, P. A., Soclof, S. I., 11th Photovoltaïc specialists Conference, Phoenix, May 1975.

[11] Selezneva, M. A., Kuprivanova, T. A., Ditsman, S. A., Izv. Akad. Nauk SSSR Ser. Fiz. 38 (1974) 2328.

[12] Bell, R. O., Serreze, H. B., Wald, F. V., 11th Photovoltaïc Specialists Conference, Phoenix, May 1975.
[13] Gu, J., Kitahara, T., Fijita, S., Sakaguchi, T., Japan J. Appl. Phys. 14 (1975) 499.

[14] Bouazzi, A., Mimila Arroyo, J., Conf. Int. Electricité Solaire, Toulouse March.

[15] Bernard, J., Lançon, R., Paparoditis, C., Rodot, M., Revue Phys. Appl. 1 (1966) 211.

[16] L. E. P. (Paris) Press communiqué, november 1971.

[17] Mimila Arroyo, J., Bouazzi, A., Cohen-Solal, G., Revue Phys. Appl. 12 (1977).

[18] Bonnet, D., Rabinhorst, H., 9th Photovoltaïc Specialists Conference, Silver Springs, May 1972.

[19] Fahrendruch, A. L., Vasilchenko, V., Buch, F., MitChell, K., Bube, R. H., Appl. Phys. Lett. 25 (1974) 605.

[20] Cohen-Solal, G., Svob, L., Marfaing, Y., Janik, E., CASTro, E., 9th Photovoltaïc Specialists Conference, Silver Springs, May 1972.

[21] Besson, J., Nguyen Duy, T., Gauthier, A., Palz, W., Martin, C., Vedel, J., 11th Photovoltaïc Specialists Conference, Phoenix, May 1975.

[22] James, L. W., Moon, R. L., Appl. Phys. Lett. 26 (1975) 467. 